\title{
'Regional Trade Courts' in the Shadow of WTO Dispute Settlement System: The Paradox of Two Courts
}

DOI:

10.3366/ajicl.2020.0300

\section{Document Version}

Accepted author manuscript

Link to publication record in Manchester Research Explorer

\section{Citation for published version (APA):}

Ngangjoh Hodu, Y. (2020). 'Regional Trade Courts' in the Shadow of WTO Dispute Settlement System: The Paradox of Two Courts. African Journal of International and Comparative Law, 27.

https://doi.org/10.3366/ajicl.2020.0300

\section{Published in:}

African Journal of International and Comparative Law

\section{Citing this paper}

Please note that where the full-text provided on Manchester Research Explorer is the Author Accepted Manuscript or Proof version this may differ from the final Published version. If citing, it is advised that you check and use the publisher's definitive version.

\section{General rights}

Copyright and moral rights for the publications made accessible in the Research Explorer are retained by the authors and/or other copyright owners and it is a condition of accessing publications that users recognise and abide by the legal requirements associated with these rights.

\section{Takedown policy}

If you believe that this document breaches copyright please refer to the University of Manchester's Takedown Procedures [http://man.ac.uk/04Y6Bo] or contact uml.scholarlycommunications@manchester.ac.uk providing relevant details, so we can investigate your claim.

\section{OPEN ACCESS}


'Regional Trade Courts' in the Shadow of WTO Dispute Settlement System: The Paradox of Two Courts

Yenkong Ngangjoh-Hodu*

Abstracts

As of May 2018, over 650 notifications of RTAs had been received by the WTO Secretariat. Of these, 287 were in force. While the content of the WTO DSU has largely been replicated in most of the regional adjudicatory bodies, emerging features of some of these RTAs are substantially out of line with the WTO DSU. While some RTAs cover aspects currently alien to the WTO, the degree of liberalisation contained within others seems remarkably deeper than under the WTO. Two distinct questions are therefore addressed in this paper. The first is whether the proliferation of RTAs threatens in any way the existence of the WTO dispute settlement system, while the second concerns the extent to which this fragmented patchwork of 'regional trade courts' contributes to the development of international law. In order to tackle these issues, the paper will first explore existing international rules relating to regional trade arrangements.

\section{Introduction}

The fast-moving political economy of international relations in recent years has confirmed the willingness of nation-states to readily cede/share aspects of their economic sovereignty with other states or supranational institutions. While the notion of state sovereignty has been debated vigorously within academic scholarship over the years, ${ }^{1}$ there is little doubt that states are more willing than ever before to 'share' with each other aspects of their external

\footnotetext{
*Professor of International Economic Law, University of Manchester School of Law. I would like to thank Jean D'Aspremont for his valuable comments on the draft of the paper as well as all the participants at the $5^{\text {th }}$ AfSIL Annual Conference for their valuable comments on this paper when it was presented. Please, contact the author of this paper with any comments at: yenkong.ngangjohhodu@manchester.ac.uk The normal disclaimer applies

${ }^{1}$ See for instance, Samantha Besson, 'Sovereignty, International Law and Democracy', 22:2 European Journal of International Law (EJIL) (2011) pp. 373-387; Ryan Mitchell, 'Sovereignty and Normative Conflict: International Legal Realism as a Theory of Uncertainty', 58:2 Harvard International Law Journal (HILJ) (2017) pp. 9-59,; Edward James Kolla, Sovereignty, International Law and the French Revolution (Cambridge University Press, 2017).
} 
economic sovereignty in the form of trade liberalisation. ${ }^{2}$ This readiness to open up what would have been seen several decades ago as being within the exclusive province of individual states is necessitated by what is seen as the contemporary world of interconnectivity. ${ }^{3}$ At the same time, it is worth noting that the clustering of states by a common bond of policy has occurred for many decades, ${ }^{4}$ although the current fragmentation of international trade rules has generated a lot of concern about the effectiveness of multilateralism. ${ }^{5}$ It may be seen that regionalism par excellence allows like-minded states or states with similar concerns, such as security or trade, to align themselves with each other. Yet, whenever multilateral trade negotiations move toward reducing most-favoured nation (MFN) tariffs, developing countries benefiting from such trade preferences worry about the impacts of such reductions on their trade preferences in key markets. There has been an unprecedented increase in the number of preferential trade agreements being concluded by World Trade Organization (WTO) Members. These include free trade agreements (FTAs), agreements establishing customs unions and partial scope agreements. According to the WTO Secretariat, as of May 2018, over 650 notifications of regional trade agreements (counting goods, services and accessions separately) had been received by the GATT/WTO. Of these, 287 were in force. ${ }^{6}$

In order to ensure that the increase in the number of RTAs does not diminish the overarching object and purpose of the WTO, in December 2006, the General Council of the WTO adopted a Transparency Mechanism to clarify and strengthen RTAs notification obligations of WTO

\footnotetext{
2 Although the true content of sovereignty is difficult to pin down with certainty, international courts and tribunals have closely associated the notion of independence with the concept of sovereignty. See, for instance, the statement of Judge Huber in the Island of Palmas (Miangas) case (United States v. The Netherlands), 2 U.N. Rep. Intl. Arb. Awards 829.

${ }^{3}$ See, for instance, Henry G. Schermers and Niels M. Blokker, International Institutional Law: Unity within Diversity, $5^{\text {th }}$ revised edition (Martinus Nijhoff, Leiden, 2011); Jean d'Aspremont, 'The Law of International Organizations and the Art of Reconciliation: From Dichotomies to Dialectics', 11: 2 International Organizations Law Review (2014) pp. 428-453.

${ }^{4}$ Article 21 of the Covenant of the League of Nations provided that '[n]othing in this Covenant shall be deemed to affect the validity of international engagements such as treaties of arbitration or regional understanding like the Monroe doctrine for the maintenance of peace'. The corollary of this provision is Article 52(1) of the United Nations Charter, which encourages regionalism among members of the United Nations (UN).

${ }_{5}^{5}$ For an extensive discussion on RTAs and the puzzles surrounding their formation and existence, see Lorand Bartels \& Federico Ortino, Regional Trade Agreements and the WTO Legal System (Oxford, 2006); and Roberto V. Fiorentino, Luis Verdeja and Christelle Toqueboeuf, The Changing Landscape of Regional Trade Agreements, WTO Secretariat Discussion Paper No. 12, (2007) and on fragmentation, see Broude, Tomer, and Yuval Shany, eds. Multi-Sourced Equivalent Norms in International Law. (Oxford: Hart, 2011), Margaret A Young ed.,Regime Interaction in International Law: Facing Fragmentation, (CUP, 2015).

${ }^{6}$ See https://www.wto.org/english/tratop_e/region_e/region_e.htm
} 
members. ${ }^{7}$ Consistent with paragraph 47 of the Doha Ministerial Declaration, the 2006 enhanced Transparency Mechanism is to be implemented on a provisional basis pending a more permanent mechanism to be adopted as part of the Doha Round of Trade Negotiations. ${ }^{8}$ Transparency as one of the fundamental aspects of WTO trade liberalisation agenda is defined as "the degree to which trade policy and practices, and the process by which they are established, are opened and predictable."9 Apart from promptly making available relevant information to the relevant committees, WTO Members are also required to ensure that the implementation of any RTAs is done in a way that will not be counterproductive to the trade liberalisation objective of the WTO. As explained below, the objective of this paper is not to review the effectiveness of the WTO transparency mechanism on RTAs but to locate the debate on these RTAs in the context of emerging dispute settlement provisions under these RTAs vis-à-vis the WTO dispute settlement in particular and international law in general. ${ }^{10}$

The fragmentation of international trade rules has also not been without consequences in terms of the number of 'court-like' structures or third party tribunals that have appeared. ${ }^{11}$ Most regional trade agreements (RTAs) contain specific provisions on political, quasijudicial or judicial methods of resolving disputes. ${ }^{12}$ While the WTO's Dispute Settlement

\footnotetext{
${ }^{7}$ WTO General Council Decision on Transparency Mechanism for Regional Trade Agreement, (adopted, 14 December 2006), WTO Document WT/L/671, 18 December 2006. It is important to note that in 1996 the Committee on Regional Trade Agreement (CRTA) was established with a mandate to review all RTAs on trade in goods and services notified to the WTO. See CRTA terms of reference in WTO doc WT/L/127, (7 February 1996). However, as a consequence of the divergent of views among WTO Members, in July 2006, Members agreed that all RTAs notified under the Enabling Clause (by developing countries) would be notified to and examined by the Committee on Trade and Development (CTD). For a brief historical analyses on the discussions on this, see Jo-Ann Crawford, A New Transparency Mechanism for Regional Trade Agreements, 11 Singapore Year Book of International Law, (SYBIL), (2007) pp. 133-140.

${ }^{8}$ As with the other aspects of the Doha Round Trade Talks, very little progress has been made by the Rules Negotiations where Transparency on RTAs is being handled. See for instance, Report by Ambassador Dennis Francis, the then Chairman of the Negotiating Group on Rules in doc. TN/RL/W/252, (21 April, 2011).

${ }^{9}$ Walter Goode, Dictionary of Trade Policy Terms, (WTO and CUP, 2003) at p. 363.

${ }^{10}$ On transparency on RTAs in the WTO, see Crawford, 11 SYBIL (2007), pp. 133-140. For discussions on broader transparency issues in the WTO, see Gabrielle Marceau and Peter Pedersen, Is the WTO Open and Transparent? Non-governmental Organisation and Civil Society's Claims for more Transparency and Public Participation, 33: 1 Journal of World Trade (JWT) (1999) at pp. 5-49, Thomas Cottier, Preparing for Structural Reform in the WTO, 10:3 Journal of International Economic Law (JIEL) (2008) at pp. 497-508, Padideh Ala'i, From the Periphery to the Center? The Evolving WTO Jurisprudence on Transparency and Good Governance, 11:4 JIEL, (2008) at pp. 779-802, Ljiljana Biukovic, Selective Adaptation of WTO Transparency Norms and Local Practices in China and Japan, 11: 4 JIEL (2008) at pp. 803-825.
}

${ }^{11}$ Although many of these structures operate like a typical court, it is important to note that the notion of a court is very foreign in the context of world trade law. Most structures are normally called dispute settlement mechanisms, tribunals or any other name that signifies a more diplomatic structure.

${ }^{12}$ For a comprehensive study on dispute resolution in respect of RTAs, see Claude Chase, Alan Yanovich, JoAnn Crawford, and Pamela Ugaz, 'Mapping of Dispute Settlement Mechanisms in Regional Trade Agreements 
Understanding (DSU) has largely been replicated in most of the quasi-judicial and judicial methods of settling disputes under RTAs, certain emerging features of some of these RTAs are substantially out of line with the Uruguay Round project on global trade dispute settlement. While some RTAs cover aspects currently alien to the WTO, liberalisation within some of the RTAs seems at face value to be deeper than under the multilateral trading system. ${ }^{13}$ At the same time, a few of the RTAs substantively contain provisions that are in conflict with the provision of some WTO covered agreements. ${ }^{14}$ Two distinct questions are therefore addressed in this paper. The first of these is whether the proliferation of RTAs threatens in any way the existence of the WTO dispute settlement system, while the second concerns the extent to which this fragmented patchwork of 'regional trade courts' contributes to the development of international law. In order to tackle these issues, the paper will first make a brief remark on the GATT/WTO rules on regional trade agreements. The paper is structured as follows; section II briefly revisit relevant WTO rules relating to RTAs. The purpose of revisiting these rules is to demonstrate the nexus between the WTO dispute settlement system and the juridical bodies of RTAs and to establish the basis of the discussion that will follow in the subsequent sections. In this regard, section III discusses the relevance of third party tribunal in trade and investment agreement while section IV examines the nexus between the proliferation of regional dispute settlement mechanisms and the future of the WTO dispute settlement system. This section discusses whether the proliferation of RTAs with dispute settlement provisions in anyway threatens the smooth functioning or the existence of the WTO DSM. The word threaten in this article is used to refer to jurisdictional conflicts where disputing parties may elect to bring their dispute before a dispute settlement mechanism under an RTA instead of the WTO. Section V explores the contributions of regional dispute settlement to the development of international law. The paper ends with brief concluding remarks.

\footnotetext{
- Innovations or Variations on a Theme', WTO Staff Working Paper, ERSD-2013-07 (2013) (hereinafter, 'Chase et al.').

${ }^{13}$ A good example is the October 2015 Trans-Pacific Partnership Agreement between the US and 11 other countries in the Americas and Asia-Pacific region. Although the US under President Trump has pulled out of TPP, this agreement covers extended investment liberalisation as well as more extensive protection of intellectual property rights than is provided under the WTO.

${ }^{14}$ In this regard, see Peru's argument and the Appellate Body report in Peru - Additional Duty on Imports of Certain Agricultural Products, WT/DS457/AB/R, (adopted, 31 July 2015).
} 


\section{Brief remarks on WTO rules on regional trade agreements}

The notion of consent and the principle of the equality of states under international law imply that states are free to enter into as many international agreements as they wish. It is worth noting that from the perspective of international organisations law, there may be hierarchy between the constituent documents of the organisation and related treaties adopted under the auspices of the organisation. However, with the exception of rules that have the status of jus cogens from which no derogation is permitted, ${ }^{15}$ from a treaty law perspective, there is generally no hierarchy between international agreements signed by sovereign states or independent territories, whether bilateral, plurilateral or multilateral. ${ }^{16}$ As has been repeatedly discussed in previous literature, the GATT/WTO rules are exceptions to this general rule because, under the MFN principle enshrined in the WTO treaty system, on joining the WTO each country or separate customs territory agrees not to enter into a preferential trade regime that is inconsistent with GATT/WTO obligations. ${ }^{17}$ In other words, by joining the WTO, Members in principle agree not to discriminate against each other's citizen $^{18}$ as well as the general notion of treating each other equally. ${ }^{19}$ As a consequence, Article I (MFN) of GATT is regarded as a cornerstone of the multilateral trade system (MTS) as it obliges all 164 WTO Members to treat each other equally. ${ }^{20}$ Consequently, to ensure that RTAs operate in a manner supportive of the MTS, the WTO has rules which have to be

\footnotetext{
${ }^{15}$ For instance, by way of illustration, in spite of the obligations under Article III of GATT, a WTO Member can discriminatorily prevent the circulation of imported, materials within its territory on the grounds of their antiSemitic or racist content. In this regard, a defence of jus cogens may be invoked by the respondent. Jus cogens is seen as a peculiarity in terms of the sources of international law. It challenges the notion of voluntarism and consent-based sources of international law. On the nature of jus cogens, see Alfred Verdross, 'Forbidden Treaties in International Law', 31 American Journal of International Law (1937), pp. 571-592; Mark Janis, 'Nature of jus cogens', 3 Connecticut Journal of International Law (1988), pp. 359-363; Gennady M. Danilenko, 'International Jus Cogens: Issues of Law-Making', 2: 1 European Journal of International Law (1991); Ulf Linderfalk, 'The Source of Jus Cogens Obligations - How Legal Positivism Copes with Peremptory International Law', 82: 3 Nordic Journal of International Law (2013), pp. 369-389; Jean D'Aspremont, Jus Cogens: A Social Construct without Pedigree, 46 Netherlands Yearbook of International Law, (2016).
}

\footnotetext{
${ }^{16}$ Hierarchy may only occur in exceptional situations such as the case of the WTO where one treaty puts one above another, otherwise the general rules on conflict resolution will apply; i.e. lex posterior and lex specialis / lex generalis rules.

${ }^{17}$ Such other international trade agreements must conform to the requirements of Article XXIV of GATT 1994 or Article V of GATS. The same is true for preferential trade regimes involving least developed countries (LDCs) and developing countries notified to the WTO on the basis of the Enabling Clause. For rules on conflict resolution in relation to the WTO, see Joost Pauwelyn, Conflict of Norms in Public International Law: How WTO Law Relates to other Rules of International Law (Cambridge University Press, 2003).

${ }^{18}$ On the basis of the National Treatment Principle littered around different GATT/WTO provisions.

${ }^{19}$ On the basis of the MFN principle.

${ }^{20}$ Article III of GATT also lays down similar obligations in respect of an individual WTO Member's treatment of products within its territory.
} 
followed by its Members when concluding such agreements. These rules are laid down in Article XXIV of GATT 1994, Article V of GATS and the Enabling Clause ${ }^{21}$ and are binding on the 164 Members of the WTO. ${ }^{22}$ As there is an established body of scholarship on WTO rules on RTAs, ${ }^{23}$ this paper will not examine the content of these rules here. However, it suffices to mention here that there are three legal bases for the formation of preferential trading arrangements in the WTO. These are Article XXIV of GATT 1994, which regulates agreements covering trade in goods; Article V of GATS relating to agreements covering trade in services; and the Enabling Clause which authorises the exchange of tariff preferences among developing countries as well as non-reciprocal preferences between developed countries on the one hand and developing countries and LDCs on the other.

\section{The relevance of third party tribunals in trade and investment agreements}

We now turn our attention to the concept of dispute settlement or third party tribunals in trade and investment agreements. Addressing the concept of dispute settlement is very relevant to addressing the core research questions of this paper, i.e., the possible threat posed by regional disputes settlement mechanisms to the functioning of the WTO DSM and their possible contributions to the evolution or development of international law. Firstly, it is difficult to understand what a dispute settlement mechanism can achieve without first understanding what a dispute means. Secondly, it is difficult to contextualise the contributions of such mechanism to the development of international law without understanding what a dispute is and or why disputes have been frequently or not frequently settled by one of such mechanisms. It is therefore, important to understand what a dispute really means and how international courts and tribunals have employed the term over the years.

\footnotetext{
${ }^{21}$ There is no comparable provision to Article XXIV of GATT 1994 and Article V of GATS in the TRIPS Agreement. There are limited exceptions to the MFN principle in the TRIPS Agreement.

22 This is the number of WTO Members as of July 2017.

${ }^{23}$ See further analyses on this by Won-Mog Choi, Legal Problems of Making Regional Trade Agreements with Non-WTO-Member States, 8: 4 JIEL (2005), Pp. 825-860, Erich Vranes, The WTO and Regulatory Freedom: WTO Disciplines on Market Access, Non-Discrimination and Domestic Regulation Relating to Trade in Goods and Services, 12: 4 JIEL (2009), pp. 953-987, Rudolf Adlung and Peter Morrison, Less than the GATS:

'Negative Preferences' in Regional Services Agreements, 13:4 JIEL, (2010), pp. 1103-1143, Ngangjoh Hodu, Regionalism in the WTO and the Legal Status of a Development Agenda in the EU/ACP Economic Partnership Agreement (July 1, 2009). Nordic Journal of International Law, Volume 78, Issue 2, (2009) pages 225-248, Thomas Cottier and Markus Krajewski, What Role for Non-Discrimination and Prudential Standards in International Financial Law?, 13: 3 JIEL, (2010), Pp. 817-835.
} 
Although almost all regional, bilateral or multilateral agreements, whatever their nature, endorse the peaceful settlement of disputes as an important aspect of the agreement, ${ }^{24}$ the true meaning of what constitutes a dispute for the purpose of dispute settlement was once a contested issue. The very first case in which the issue arose was that of Mavrommatis Palestine Concessions, where the Permanent Court of International Justice (PCIJ) stated that '[a] dispute is a disagreement on a point of law or fact, a conflict of legal views or of interests between two persons'. ${ }^{25}$ Twenty-six years later, the International Court of Justice (ICJ) defined a dispute as 'a situation in which the two sides held clearly opposite views concerning the question of the performance or non-performance of certain treaty obligations $^{26}$.

Consequently, determination of the existence of a dispute is an important element in deciding whether to have recourse to dispute settlement and, if so, what dispute settlement mechanism (DSM) is most appropriate for the dispute at hand. Therefore, a dispute arising from an international instrument is generally viewed as involving a disagreement between two or more parties, which are typically but not exclusively states, over the interpretation and application of a trade agreement. ${ }^{27}$ In the context of trade disputes initiated within the framework of the WTO DSM, a dispute is said to arise 'when a member government believes another member government is violating an agreement or a commitment that it has made in the WTO' ${ }^{28}$ More specifically, a dispute may arise when there is 'a violation of obligations or other nullification or impairment of benefits under the covered agreements or an impediment to the attainment of any objective of the covered agreements' ${ }^{29}$ In the context of

\footnotetext{
${ }^{24}$ This approach largely reflects the will of the international community as stipulated under Article 2.3 of the UN Charter.

${ }^{25}$ Mavrommatis Palestine Concessions (Greece v. Great Britain), Judgment of 30 August 1924, 1924 PCIJ (ser. A) No. 2, at p. 11 .

${ }^{26}$ Interpretation of the Peace Treaties with Bulgaria, Hungary and Romania, Advisory Opinion of 30 March 1950 (first phase), 1950 ICJ Rep. 65, at p. 74.

${ }^{27}$ On this, see John Merills, 'The means of dispute settlement', in Malcolm D Evans (ed.), International Law, $4^{\text {th }}$ ed. (Oxford University Press, 2014), pp. 563-588.

${ }^{28}$ See http://www.wto.org/english/tratop_e/dispu_e/dispu_e.htm

${ }^{29}$ See Article 23.1 of the DSU. In this regard, the three different types of complaint that exist in the WTO are violation, non-violation and situation complaints. See also Article 26 of the DSU and Article XXIII of GATT 1994. A great deal has been written about the types of complaints handled by the WTO DSM. On some of the writing on this topic, see John H. Jackson, 'The WTO Dispute Settlement Understanding--Misunderstandings on the Nature of Legal Obligation', 91: 1 American Journal of International Law (1997), pp. 60-64; Ngangjoh Hodu, 'Pacta sunt servanda and complaints in the WTO dispute settlement', 1: 2 Manchester Journal of International Economic Law, (MJIEL) (2004); Frieder Roessler and Petina Gappah, 'A Re-Appraisal of Non-
} 
many existing RTAs, the term 'dispute' simply means a situation where there is a conflict of views with regard to the implementation or non-implementation of a provision or provisions of such RTAs. ${ }^{30}$

However, the landscape of these fragmented dispute settlement facilities under various international agreements has radically shifted so that the proliferation of these bodies has been seen by some academics as the 'single most important development of the post-Cold War' era. ${ }^{31}$ Dispute settlement is at the heart of inter-state cooperation and recent international economic institutions have placed emphasis 'on dispute-settlement mechanisms and on institutions to support compliance with those mechanisms' ${ }^{32}$ For example, since the establishment of the WTO in 1995, its two-tier DSM has been one of the organisation's most recognised and functional elements. To date, WTO Members have initiated over 547 disputes, underscoring the central role the dispute settlement system plays in the MTS. ${ }^{33}$ Similarly, when NAFTA was established the three contracting parties instituted an elaborate DSM for trade and investment disputes. The same holds for ASEAN, which has been working on the improvement of its DSM with the introduction of the 2004 Enhanced Dispute Settlement System and the 2010 Protocol on Dispute Settlement. ${ }^{34}$

Introducing dispute settlement provisions in inter-state agreements is consistent with the general notion that those agreements are the constituent elements of binding international law requiring good faith compliance by states. ${ }^{35}$ Typically, dispute settlement may serve as a tool to ensure compliance with the agreed results of protracted negotiations by states. And

Violation Complaints Under the WTO Dispute Settlement Procedures', in Patrick F. J. Macrory et al. (eds.), The World Trade Organization: Legal, Economic and Political Analysis (Springer, 2005) pp. 1371-1387. On the interpretation of Article 23 of the DSU, see the WTO AB Report in US - Continued Suspension / Canada Continued Suspension, WT/DS320/AB/R, WT/DS321/AB/ (adopted 14 November 2008), paras. 371-373.

${ }^{30}$ On the theory of definition of legal norms, see Enrich Vranes, "The Definition of "Norm Conflict" in International Law and Legal Theory', 17: 2 European Journal of International Law (2006), pp. 395-418.

${ }^{31}$ See Romano (1999) at pp. 723-728 in Robert O. Keohane et al., 'Legalising Dispute Resolution: Interstate and Transnational', 54: 3 International Organisation (2000), pp. 457-488. Keohane et al, explain how the number of international organisations with third parties adjudicatory bodies have steadily grown. There are now almost a hundred international tribunals and courts around the world.

${ }^{32}$ Beth V. Yarbrough and Robert M. Yarbrough, 'Dispute Settlement in International Trade: Regionalism and Procedural Coordination', in Edward D. Mansfield et al. (eds.), The Political Economy of Regionalism (Columbia University Press, 1997) at p. 138.

${ }^{33}$ As of June 2018. See the WTO's website at www.wto.org

${ }^{34}$ See the 2004 ASEAN Protocol on Enhanced Dispute Settlement Mechanism, Adopted by the Economic Ministers at the 10th ASEAN Summit in Vientiane, Laos (29 November 2004), available at http://cil.nus.edu.sg/rp/pdf/2004\%20ASEAN\%20Protocol\%20on\%20Enhanced\%20Dispute\%20Settlement\%20 Mechanism-pdf.pdf and the April 2010 Protocol to the ASEAN Charter on Dispute Settlement Mechanisms at http://cil.nus.edu.sg/rp/pdf/2010\%20Protocol\%20to\%20the\%20ASEAN\%20Charter\%20on\%20Dispute\%20Sett lement\%20Mechanisms-pdf.pdf, last visited 20 August 2017.

${ }^{35}$ See Article 26 of the Vienna Convention on the Law of Treaties. 
because it is inconceivable that after protracted negotiations it will be possible to draft an agreement capable of covering all future eventualities, dispute settlement may also be seen more as an essential instrument to make sense of the deal struck, thus enhancing the security and predictability of the of the treaty in question. ${ }^{36}$ As stated in Article 3.2 of the DSU, the dispute settlement system is:

'a central element in providing security and predictability to the multilateral trading system. The Members recognize that it serves to preserve the rights and obligations of Members under the covered agreements, and to clarify the existing provisions of those agreements in accordance with customary rules of interpretation of public international law.'

In spite of the generally acceptable role third party tribunals should play in RTAs articulated above, there is ongoing debate as to the future role of dispute resolution in trade and investment agreements both at regional and at multilateral level. ${ }^{37}$ In the context of the WTO, for instance, one school holds that dispute settlement should be strictly limited to clarifying the provisions of the WTO Agreement and its covered agreements in a manner consistent with the common intentions of WTO Members. ${ }^{38}$ On the other hand, a more radical school views the dispute settlement system in terms of an activist's court whose role is to make sense of relevant agreements, fill gaps where necessary and eventually set precedents for future rulings. ${ }^{39}$ This view, which is mostly held by economists who employ contract theory to analyse the WTO dispute settlement system, further contends that dispute settlement may

\footnotetext{
${ }^{36}$ It is important to note that most, if not all, international agreements do not see DSMs as being able to add to or diminish the negotiated rights and obligations of contracting parties. See, for instance, Articles 3.2 and 19.2 of the DSU.

${ }^{37}$ This debate is more prominent in the context of investors states dispute settlement as discussed in Charles Brower \& Stephen. Schill, 'Is Arbitration a Threat or a Boon to the Legitimacy of International Investment Law, 9 Chicago Journal of International Law (2009). For a critical discussion see Gus Van Harten, 'Five Justifications for Investment Treaties: A Critical Discussion', 2: 1Trade, Law and Development , (2010), 19, R. Kreindler, 'Part II Chapter 6: Parallel Proceedings: A Practitioner's Perspective' in Michael Waibel, Asha Kaushal et al. (eds.), The Backlash against Investment Arbitration (Kluwer Law International, 2010), Vera Korzun, The Right to regulate in Investor-State Arbitration: Slicing and Dicing Regulatory Carve - Outs, 50 Vanderbilt Journal of Transnational Law, (2017), pp. 373-380, etc.

${ }^{38}$ In this regard, strictly adhering to what they see as the spirit of Articles 3.2 and 19.2 of the DSU.

${ }^{39}$ Making an economic analysis of the role dispute settlement should play in trade agreements, Maggi and Staiger see dispute settlement under the WTO as being more about 'filling gaps in the agreement where it is silent than about enforcing clearly-stated obligations'. Giovanni Maggi \& Robert W. Staiger, 'The Role of Dispute Settlement Procedures in International Trade Agreements', 126 Quarterly Journal of Economics, Vol. (2011), p. 475. The latter view is clearly inconsistent with the general understanding (see Articles 3.2 and 19.2 of the DSU) that rulings and recommendations made by panels and the $\mathrm{AB}$ are not to be seen as adding to or reducing the obligations of Members.
} 
also serve as a mechanism to complete 'an incomplete contract' previously negotiated by nation-states. $^{40}$

In the context of RTAs that contain provisions on investment, the practice of submitting investment disputes to international arbitration either under the auspices of the International Centre for Settlement of Investment Disputes (ICSID) or the UN Commission on International Trade Law (UNCITRAL) has sparked global controversy. As Judge Schwebel remarked in 2014:

'Opponents of investor-state arbitration claim that it faces a "legitimacy crisis." There are three essential contentions advanced by such critics: (1) tribunals are biased toward multinational enterprises; (2) arbitration is asymmetrical because of investors' freedom to bring claims against states, while states cannot bring claims against investors; and (3) arbitral awards are often conflicting. These criticisms are more colorful than they are cogent. ${ }^{41}$

Despite these criticisms, proponents of investor-state DSMs have pointed to what they see as successes of states in disputes with investors in recent years as justification for maintaining state-investor DSMs in regional trade agreements or bilateral investment treaties. ${ }^{42}$ Nonetheless, there is a view that investor-state dispute settlement systems constrain countries' ability to adopt measures for the public good, including laws and regulations to protect the environment. For instance, the German Government threatened to veto the recently negotiated FTA between the EU and Canada ${ }^{43}$ ostensibly because of the inclusion of an investor-state dispute settlement system. ${ }^{44}$ More recently, due to the concerns of the Belgian public, on 6 September 2017, Didier Reynders, Deputy Prime Minister and Minister of Foreign Affairs of Belgium requested the Court of Justice of the European Union (CJEU) for an opinion on the compatibility of the Investment Court System (ICS) in CETA with the

\footnotetext{
${ }^{40}$ Giovanni Maggi \& Robert W. Staiger, 'The Role of Dispute Settlement Procedures in International Trade Agreements', 126 Quarterly Journal of Economics, (2011), p. 476.

${ }^{41}$ Stephen M. Schwebel, 'In defense of bilateral investment treaties', Columbia FDI Perspectives: Perspectives on topical foreign direct investment issues, No. 135 (24 November, 2014), Columbia Center on Sustainable Investment.

42 ibid., referring to Susan Frank, 29 ICSID Review (winter 2014), pp. 66-89.

${ }^{43}$ CETA entered into force on a provisional basis on the 21 September 2017. It is important to note that the few parts of CETA that did not enter into force on provisional basis concerns investment including the new ICS. See European Commission - Press Release, EU - Canada Trade Agreement Enters into force, Brussels, 20 September 2017. Available at http://europa.eu/rapid/press-release_IP-17-3121_en.htm (accessed, May 2018).

${ }^{44}$ See Kay-Alexander Scholz, 'Germany puts CETA free trade deal with Canada on hold', Deutsche Welle (September 2014), available at http://www.dw.de/germany-puts-ceta-free-trade-deal-with-canada-on-hold/a17940554, accessed on 29 December 2014.
} 
European Treaties. ${ }^{45}$ Similar views were also expressed in the context of the Transatlantic Trade and Investment Partnership Agreement between the EU and the US. In 2014 the French minister responsible for foreign trade voiced the French Government's opposition to the inclusion of an investor-state dispute settlement system in the Agreement and that contributed to the apparent suspension of the negotiations. ${ }^{46}$

International economic disputes, especially in the trade and investment fields, may arise for a number of reasons, including anticipation of a likely breach of a treaty by a party to the agreement ${ }^{47}$ or an actual breach of a treaty obligation. With this in mind, the purpose of dispute settlement will be to strike a careful balance between the rights and obligations of the parties consistent with the original negotiated commitments. In some cases no actual violation may occur, but the purpose of the dispute settlement - whether in the form of a third party adjudicatory body, as in the WTO, or a more diplomatic process,${ }^{48}$ such as consultation, negotiation, conciliation and mediation - will be to compensate for the loss of a legitimate expectation. ${ }^{49}$ Whether contracting parties to international agreements decide to opt for a more diplomatic or a more legalistic mechanism for resolving conflicts, this paper sees DSMs as instruments to provide positive solutions to disputes.

\section{Does the proliferation of regional 'courts' or dispute settlement mechanisms threaten the existence of the WTO dispute settlement system?}

\footnotetext{
${ }^{45}$ See the request on the web site of the government of Belgium at https://diplomatie.belgium.be/sites/default/files/downloads/ceta_summary.pdf A similar was delivered in early 2017 with regard to the EU-Singapore FTA. See Opinion 2/15 of the European Court of Justice on the Competence of the European Union in Trade Policy, see $\$ 285$ - 293 of the Opinion of the Court of Justice of the EU on the division of competences between the European Union and the member states on the content of the 2013/2014 free trade agreement with Singapore (16 May 2017).

${ }^{46}$ See Anne-Claude Martin \& Cécile Barbière (translated by Samuel White), 'French government will not sign TTIP agreement in 2015', 17 November 2014 (updated: 20 Nov 2014), available at http://www.euractiv.com/sections/trade-society/french-government-will-not-sign-ttip-agreement-2015-310037, last visited 3 December 2014.

${ }^{47}$ This is the case in respect of anti-dumping and subsidies and countervailing measures under the WTO. See in this regard Article VI:1 of GATT 1994, Article 3.7 of the Antidumping Agreement, and Article 15.7 of the Agreement on Subsidies and Countervailing Measures.

${ }^{48}$ Dispute settlement under GATT 1947 is an example of such a diplomatic process. See David Palmeter and Petros C Mavroidis, Dispute Settlement in the World Trade Organization: Practice and Procedure (Springer, 1999); Robert E Hudec, Enforcing International Trade Law: The Evolution of the Modern GATT Legal System (Butterworth, 1993); and Michael J. Trebilcock \& Robert Howse, The Regulation of International Trade, 3rd ed. (Routledge, 2005).

49 This is the case with situation and non-violation complaints in the WTO dispute settlement system.
} 
At a time when the negotiating arm of the MTS is largely seen as ineffective, ${ }^{50}$ the role of the WTO adjudicatory body remains critical in preserving the security and predictability of the trading system. While it does have various shortcomings, ${ }^{51}$ it has largely been effective in ensuring that WTO rules are complied with. With over 547 cases having been initiated by June 2018 under the WTO DSM, ${ }^{52}$ it is difficult to disregard the uniqueness of the system in terms of breaking new jurisprudential ground. ${ }^{53}$ Although over 450 RTAs with dispute resolution mechanisms have been notified to the WTO, very few cases have been resolved through these fragmented third party adjudicatory bodies. ${ }^{54}$ While it is hard to assess the success of the DSMs provided under the RTAs, it is clear from the number of cases brought within the WTO dispute settlement system, as well as from their subject matter and the parties involved, that there is a preference for the latter over the former.

Nevertheless, one simple question comes to mind when thinking of the emergence of this fragmented patchwork of multiple regional trade tribunals - does it threaten the existence of WTO DSM? As indicated in the introduction of this paper, the word threaten in this article is used to refer to jurisdictional conflicts where disputing parties may elect to bring their dispute before a dispute settlement mechanism under an RTA instead of the WTO. This could likely happen in disputes between developing countries members who may find the WTO dispute settlement process too expensive. In other words, it is theoretically possible that the explosive growth of RTAs with DSM may deviates disputes from the WTO DSM to RTAs DSM. ${ }^{55}$

\footnotetext{
${ }^{50}$ Some of the criticisms of the WTO and the consistent lack of progress with the negotiating arm of the system can be found in Peter Sunderland, The Doha Development Agenda: Political Challenges to the World Trading System - A Cosmopolitan Perspective, 8:2 JIEL,(2005), pp. 363-375; Debra Steger, The Culture of the WTO: Why it need to Change, 10: 3 JIEL (2007), pp. 483-495; Joost Pawelyn, New Trade Policy for the $21^{\text {st }}$ Century, 11: 3 JIEL(2008), pp. 559-573; Matthew Kennedy, Two Single Undertaking - Can the WTO Implement the Results of a Round?, 14: 1 JIEL (2011), pp. 77-120 etc.

${ }^{51}$ For a discussion on some of the shortcomings of the WTO DSM, see for instance, Ngangjoh-Hodu \& Zhang, The Political Economy of WTO Implementation and China's Approach to Litigation in the WTO, (Edward Elgar, 2016).

${ }^{52}$ It is important to note that some of these cases were resolved at the consultation stage. However, in comparison to fewer than 170 cases brought before the ICJ in its almost 70 years of existence, the number of disputes settled by the WTO DSM is very impressive. For an up-to-date list of cases initiated under the WTO DSM, see https://www.wto.org/english/tratop_e/dispu_e/dispu_status_e.htm, last visited June 2018.

${ }^{53}$ See Andrew D. Mitchell, Legal Principles in WTO Disputes (Cambridge University Press, 2011); Graham Cook, A Digest of WTO Jurisprudence on Public International Law Concepts and Principles (Cambridge University Press, 2015).

${ }^{54}$ It is of course true that because of the secretive nature of some of the disputes settled through RTAs' dispute resolution mechanisms as well as the lack of a central database on international trade dispute settlement reports, it is difficult to say with certainty how many disputes have gone through each of these mechanisms.

${ }^{55}$ As will be seen in the discussion that follows, there is currently no evidence to suggest that this is the case.
} 
While GATT Article XXIV and GATS Article V deal with the formation of RTAs ${ }^{56}$, there is no equivalent provision on how to harmonise the law and policy under the two regimes. The situation of competition between the two systems may happen in a possible scenario of dwindling enthusiasm in the world trading system. ${ }^{57}$

However, to prevent the WTO members from resorting to unilateralism whenever there is a breach of their treaty rights, ${ }^{58}$ Article 23 of the DSU requires members to address all their disputes to the WTO DSM to the exclusion of any other DSM. ${ }^{59}$ This means that the WTO DSM has compulsory and as has been contended by some scholars, ${ }^{60}$ exclusive jurisdiction over all matters arising under any of the WTO covered agreements. The compulsory and exclusive nature of the jurisdiction of the WTO is arguably one of the most important aspects of the identity of the WTO DSM. ${ }^{61}$ Paradoxically, this unique aspect of the identity does not seem to prevent the emergence of other regional trade courts. On the basis of GATT Article XXIV as well as GATS Article V WTO members are not prohibited from including DSM provisions under their various RTAs. Although there is no uniformity on the nature of the

\footnotetext{
${ }^{56}$ It is important to note as discussed above that many RTAs by Developing countries as well as non-reciprocal trade preferences are also notify to the WTO on the basis of the Enabling Clause.

${ }^{57}$ On competing jurisdiction of international Courts and Tribunals, see generally Joost Pauwelyn, Conflict of Norms in Public International Law - How WTO Law Relates to Other Rules of International Law, (CUP, 2003) and Yuval Shany, The Competing Jurisdiction of International Courts and Tribunals, (OUP, 2003).

${ }^{58}$ It is of course, important to bear in mind recent development regarding unilateral imposition of tariffs on steel and aluminium from some WTO members including the European Union by the United States. See for instance, US tariffs: Steel and aluminium levies slapped on key allies, BBC World news, 31 May 2018, See also Press

Release, European Commission reacts to the US restrictions on steel and aluminium affecting the EU

European Commission, 31 May 2018.

${ }^{59}$ Pursuant to DSU Article 23(1), "When Members seek the redress of a violation of obligations or other nullification or impairment of benefits under the covered agreements or an impediment to the attainment of any objective of the covered agreements, they shall have recourse to, and abide by, the rules and procedures of this Understanding".

${ }^{60}$ See Debra P. Steger, The Jurisdiction of the World Trade Organization, Proceedings of the 98th Annual Meeting of the American Society of International Law, (2004), pp. 142-147; Peter Van den Bossche and Zdouc, The Law and Policy of the World Trade Organization, $4^{\text {th }}$ ed., (CUP, 2017), pp. 168-169.
}

${ }^{61}$ For instance, under the ICJ "States have the option to accept or disregard the jurisdiction of the Court. Even if states give their consent to the jurisdiction of the Court, they can do so "under the terms and conditions they determine themselves". The same can be said with regards to the jurisdiction of the International Tribunal for the Law of the Sea (ITLOS). For more on this, see. Stanimir A. Alexandrov, The Compulsory Jurisdiction of the International Court of Justice: How Compulsory Is It? 5: 1 Chinese Journal of International Law (2006), pp. 29-38 
DSM under RTAs, some of the DSM under RTAs either provide for choice of forum clause ${ }^{62}$ or compulsory jurisdiction ${ }^{63}$. Yet, the compulsory and exclusive jurisdiction under RTAs DSM overlaps with DSU Article 23 which places the same requirements on WTO members. ${ }^{64}$ In the absence of any legal clarification on the relationship between WTO DSU and DSM under RTAs, it is theoretically possible to see DSM under RTAs with compulsory jurisdiction as undermining the rights of WTO members to resort to WTO DSM. ${ }^{65}$

Therefore, it is difficult to read about the proliferation of RTAs accompanied by new DSMs without at the same time pondering whether these tribunals overlap jurisdictionally with the existing mechanism under the WTO. For instance, it is quite possible for one dispute between two NAFTA parties or SADC parties ${ }^{66}$ to be brought before the WTO dispute settlement system and for another to be brought before a NAFTA Chapter 20 panel or SADC dispute

\footnotetext{
${ }^{62}$ See for instance, Article 22.6 of the Korea-US FTA as well as Article 1(2) of the Olivos Protocol in relation to WTO-MERCOSUR dispute settlement, and more recently, Article 28.4 of the Comprehensive and Progressive Agreement for Trans-Pacific Partnership (CPTPP), which provide for a choice of forum between CPTPP DSM and the WTO. .

${ }^{63}$ See for instance, NAFTA Article 2005.4 which provides that where a dispute relates to SPS or standards, the respondent reserve the right to insist that the dispute be brought under NAFTA. Similarly, according to Article 28.5 of the Lisbon Treaty "[t]he Court of Justice of the European Union shall... have jurisdiction in disputes concerning measures adopted by organs of a body incorporated under Union law" to the exclusion of any other courts. Article 42.1 of the Cartagena Agreement Creating the Court of Justice of the Andean Community contains a similar exclusive jurisdiction clause. See also Article 32 of the Southern Africa Development Community (SADC), Protocol on Trade.

${ }^{64}$ See Article DSU Article 23.

${ }^{65}$ For a discussion on overlapping jurisdiction in the context of specific WTO dispute, see Caroline Henckels, Overcoming Jurisdictional Isolationism at the WTO-FTA Nexus: A Potential Approach for the WTO, 19: 3 EJIL, (2008), pp. 571-599 as well as Leonila Guglya, The Interplay of International Dispute Resolution: the Softwood Lumber Controversy, 2:1 Journal of International Dispute Settlement (JIDS), (2011), pp. 175-207. ${ }^{66}$ Article 32 of the SADC Protocol states that ' [ $[$ t]he rules and procedures of Annex VI shall apply to the settlement of disputes between Member States concerning their rights and obligations under this Protocol'. (emphasis by author). See http://www.sadc.int/files/4613/5292/8370/Protocol_on_Trade1996.pdf, last visited 29 December 2016.
} 
settlement mechanism respectively. ${ }^{67}$ This is exactly what happened in Mexico - Tax Measures on Soft Drinks and Other Beverages,${ }^{68}$ in the context of NAFTA and the WTO. In that case, Mexico imposed a series of tax measures on soft drinks and other beverages that use a sweetener other than cane sugar. The US challenged these measures before the WTO DSM on the basis of their inconsistency with National Treatment provisions under Articles III:2 and III:4 of GATT. As has been argued by some commentators:

'Mexico, for its part, asserted that it had initiated earlier panel proceedings under NAFTA Article 2008 because the United States was acting inconsistently with its market access obligations for Mexican sugar under NAFTA. Mexico, therefore, claimed that its measures were merely a defence of its market access rights, on the basis that it could not take further action under NAFTA, since the United States had refused to appoint its panellists and had also instructed the United States' section of the NAFTA's Secretariat not to do so. ${ }^{69}$ In view of these facts, Mexico requested the panel to decline jurisdiction in the case. ${ }^{, 70}$

However, in rejecting Mexico's request, the panel stated that "...under the DSU, it had no discretion to decide whether or not to exercise its jurisdiction in a case properly before it..."71 On appeal, the AB also rejected Mexico's arguments relating to the panel's jurisdiction and Mexico's arguments on the failure of the US to respect its obligations under NAFTA. ${ }^{72}$ According to the $\mathrm{AB}$, the panel will not be able to perform its duty of providing an objective assessment as required by DSU Article 11 if it was to simply decline

\footnotetext{
${ }^{67}$ On this issue, see Joost Pauwelyn, 'Going Global, Regional, or Both? Dispute Settlement in the Southern African Development Community (SADC) and Overlaps with the WTO and Other Jurisdictions', 13:2 Minnesota Journal of Global Trade (2004), pp. 231-302; Joost Pauwelyn, Conflict of Norms in Public International Law: How WTO Law Relates to Other Rules of International Law (Cambridge University Press, 2004); and William J. Davey, 'Dispute Settlement in the WTO and RTAs: A Comment', in Lorand Bartels and Federico Ortino (eds.), Regional Trade Agreements and the WTO Legal System (Oxford University Press, 2006), pp. 343-357, Henry Gao et al, Saving the WTO from the Risk of Irrelevance: The WTO Dispute Settlement Mechanism as a 'Common Good' for RTA Disputes, 11:4 JIEL (2008), pp. 899-925;Armand C. M. de Mestral, Dispute Settlement Under the WTO and RTAs: An Uneasy Relationship, 16:4 JIEL, (2013), pp. 777-825,; Regionalism and Overlap in Investment Treaty Law: Towards Consolidation or Contradiction?, 17:2 JIEL (2014), pp. 271-298. .

${ }^{68}$ AB Report, WT/DS308/AB/R, adopted 24 March 2006.

${ }^{69}$ Mexican appellant's submission, paras. 15-27; and AB Report, para. 54, footnote 106.

${ }^{70}$ See Ngangjoh-Hodu, 'Proceedings and Implementation in the WTO Dispute Settlement System in 2006', 3: 3 Manchester Journal of International Economic Law (2006), pp. 92-110.

${ }^{71}$ Panel Report, para. 7.1.

${ }^{72}$ AB Report, para. 78.
} 
jurisdiction in favour of a NAFTA tribunal. ${ }^{73}$ Similarly, in Argentina - Poultry, Argentina strenuously argued that Brazil should be estopped from bringing a case before the WTO DSM as it had been previously settled by a MERCOSUR tribunal. ${ }^{74}$ In response, the panel stated that there was no limitation on Brazil to "bring WTO dispute settlement proceedings in respect of measures previously challenged through MERCOSUR,"75.The approach of the WTO DSM in these two cases shows that while the jurisdiction of the WTO DSM is compulsory, the process of dispute settlement for its members that are contracting parties to RTAs with similar DSM could be quite expensive. It is quite possible that a party that does not want to respect its international obligation may try to evade compliance with its international obligation through dispute settlement forum shopping.

Nonetheless, although the possibility of conflict of jurisdiction between the third party adjudicatory bodies provided under the RTAs and the WTO DSM remains, for practical purposes this has so far proven not to be the case. The Mexico - Soft Drinks, Argentina Poultry cases as well as Peru - Agricultural Products case ${ }^{76}$ where Peru accused Guatemala of not acting in good faith by bringing the dispute before the WTO DSM are therefore unique. ${ }^{77}$ The latter hinged on the relationship between the 2011 Guatemala - Peru FTA and WTO Agreement. ${ }^{78}$ More precisely, the FTA recognises Peru's rights to impose certain import duties on agricultural products from Guatemala in contravention of WTO Agreement on Agriculture Article 4.2. Invoking Article 31.3(c) as well as 31.3(a) of the VCLT and other relevant provisions, Peru alleged before the panel and the AB that the FTA modified its WTO

\footnotetext{
${ }^{73}$ The AB precisely stated that "[I]t is difficult to see how a panel would fulfil that obligation if it declined to exercise validly established jurisdiction and abstained from making any finding on the matter before it". See AB Report, Mexico - Soft Drink, para. 51.

${ }^{74}$ According to the Panel in this case, "[T]here is no evidence on the record that Brazil made an express statement that it would not bring WTO dispute settlement proceedings in respect of measures previously challenged through MERCOSUR. Nor does the record indicate exceptional circumstances requiring us to imply any such statement". Panel Report, Argentina-Definitive Anti-Dumping Duties on Poultry from Brazil, WT/DS24/R, (7 November 2001), para. 7.38.
}

\footnotetext{
75 Panel Report, Argentina-Definitive Anti-Dumping Duties on Poultry from Brazil, para. 7.38.

${ }^{76}$ See Appellate Body Report, Peru - Additional Duty on Imports of Certain Agricultural Products, WT/DS457/AB/R, (adopted, 31 July 2015), paras. 5.91-112.
}

\footnotetext{
${ }^{77}$ Closely related to this case is Brazil - Tyres, where Brazil had, contrary to Article XI and the Chapeau of Article XX of GATT, according to the AB, exempted members of MERCOSUR in its import bans on retreaded tyres. See AB Report, Brazil - Measures Affecting Imports of Retreaded Tyres, WT/DS332/AB/R (adopted 17 December 2007).

${ }^{78}$ See Free Trade Agreement Between Guatemala and Peru at http://investmentpolicyhub.unctad.org/IIA/country/86/treaty/3293 (last visited, December 2017).
} 
obligations toward Guatemala ${ }^{79}$. The AB however, rejected Peru's claim. Although there are instances where RTAs may cover aspects not entirely covered by the GATT/WTO treaty provisions, the jurisdiction of the WTO DSM is very broad. Consequently, it is not surprising that, in most cases, parties to RTAs still prefer to bring their disputes before the WTO DSM even when the subject matter of the dispute is within the purview of the RTA's adjudicatory mechanism. For instance, Thailand-Cigarettes ${ }^{80}$ was one of those cases that could have been settled under ASEAN DSM. Similarly, $U S-C O O L^{81}$ between the US, Canada and Mexico, could arguably have been settled under Chapter 20 of NAFTA, but the complainants decided rather to invoke the WTO DSM.

Moreover, the high reputation earned by the WTO DSM over the years together with the fact that most of the DSMs provided under RTAs remain very much untested partly explain why parties still prefer to bring their cases before the WTO DSM than before the resolution mechanisms provided under RTAs. ${ }^{82}$ As discussed above, the fact that over 547 cases have gone through the WTO DSM means that a body of jurisprudence exists that provides parties with a level of predictability as to the decision that will be reached by a WTO panel or AB in any future case. ${ }^{83}$ Furthermore, most of the DSMs provided under the different RTAs actually mirror the WTO DSU, and in some cases clearly confer jurisdiction on the WTO in the event that any forum shopping issues arise ${ }^{84}$ Because of the two-tier nature of the WTO DSM, parties are also confident that they will be able to have a 'second chance' if they fail to secure their preferred decision at the panel stage. With very limited exceptions, most of the DSMs provided under RTAs do not feature an appeal stage. ${ }^{85}$

Viewed in the light of the foregoing, the lesson we can learn here is that it is very difficult to conclude that the proliferation of DSMs under the RTAs threatens in any way the existence

\footnotetext{
${ }^{79}$ See AB Report, para. 5.17-19.

${ }^{80}$ AB Report, Thailand - Customs and Fiscal Measures on Cigarettes from the Philippines, WT/DS371/AD/R (adopted 15 July 2011).

${ }^{81}$ AB Report, United States - Certain Country of Origin Labelling (COOL) Requirements, WT/DS384, 386/AB/R (adopted 23 July 2012).

${ }^{82}$ See Peter Van den Bossch et al., 'What to do when Disagreement Strikes? The Complexity of Dispute Settlement under Trade Agreements', in Frankel and Lewis (eds.), Trade Agreements at the Crossroads (Routledge, 2012). See also Davey (2006).

${ }^{83}$ Of course, it is important to stress emphatically here that the decision in a WTO dispute applies only to the parties that brought the case. In other words, it is now a settled notion that there is no stare decisis, as it is known in the common law jurisdictions, in the WTO.

${ }^{84}$ See for instance, Article 26 of the US - South Korea FTA.

${ }^{85}$ One of the very few with an appeal stage is the 2004 ASEAN Protocol on Economic Disputes.
} 
of the WTO DSM. Although some RTAs do cover in a rather comprehensive manner some WTO-plus issues, such as competition, investment and extended services liberalisation, the WTO DSM remains a somewhat familiar structure and the procedures for requesting the establishment of a panel and for the adoption of its report are almost automatic. This is not the case in respect of the mechanisms provided under certain of the RTAs' DSMs, as was seen in the Mexico - Soft Drinks case. With the possibility of hearing multiple complaints by neutral panellists and impartial $\mathrm{AB}$ members, parties to RTAs and the WTO will likely continue to pursue their claims before the latter. Moreover, majority of DSM under RTAs even between developing and developed countries do not contain the kind of special and differential treatment under the WTO. It may therefore, be difficult for a developing country party to such RTA to elect to bring its dispute before an RTA DSM instead of WTO DSM. In light of all these, the role of the DSM under RTAs as third party adjudicatory bodies is currently very limited.

\section{What contributions have DSMs under RTAs made to the development of international law?}

Over the past few decades, international law, and in particular international economic law, has been greatly impacted by globalisation. ${ }^{86}$ Unlike other processes of norm-making in international economic law, the influence of globalisation on international trade law is sometime very subtle but also very far-reaching and usually goes unnoticed. RTAs as an engine for trade liberalisation and the promotion of economic growth, is therefore considered to be firmly rooted in the idea of globalisation and interconnectivity. Unlike the WTO DSM which has been lauded for "creating an international common law of trade", 87 DSM under

\footnotetext{
${ }^{86}$ Some of these analyses are very much reflected in Ngangjoh-Hodu, Theories and Practices of Compliance with WTO Law (Kluwer, 2012) (hereinafter 'Ngangjoh-Hodu (2012)'); There is no universally agreed definition of globalisation. However, international integration in labour, commodity and capital markets is usually used by economists to mean globalisation. On this, see Michael D. Bordo, Antu Panini Murshid, 'Globalization and Changing Patterns in the International Transmission of Shocks in Financial Markets', 25 Journal of International Money and Finance (JIMF) (2006), pp. 655-674.

${ }^{87}$ Citing Bhala, Sterio argues that the legal rules created by the WTO DSM since its inception in 1995 have undoubtedly challenge the traditional notion of state sovereignty. See Milena Sterio, The Evolution of International Law, 31: 2 Boston College International and Comparative Law Review (BCICLR) (2008), pp. 240241.
} 
RTAs have not been known for advancing judicial views that may influence the development of the law. In order to discuss the contributions or the influence of these RTAs DSMs on the development of international law, it is important to very briefly reflect on what these regional DSM were meant to do. In other words, why have contracting parties to RTAs consistently included disputes settlement provisions in their various RTAs?

As pointed out in section III of this paper, international trade disputes may arise for a number of reasons, including anticipation of a likely breach of a treaty by a party to the agreement ${ }^{88}$ or an actual breach of a treaty obligation. The purpose of dispute settlement would therefore, be to strike a careful balance between the rights and obligations of the parties consistent with the original negotiated commitments or the common intentions of the parties when an RTA was negotiated. In some cases no actual violation may occur, but the purpose of the DSM - whether in the form of a third party adjudicatory body, ${ }^{89}$ or in the form of a political or diplomatic model like India-Nepal FTA, ${ }^{90}$ would be to provide redress for the loss of a legitimate expectation. The object and purposes of DSM under most RTAs are mostly a reflection of these views. With the exception of EFTA Court ${ }^{91}$ which as an independent court that works closely with the Court of Justice of the European Union (CJEU) with objective of adjudicating on "actions brought by the EFTA Surveillance Authority against EFTA States for non-compliance with the EEA Agreement" among other things, ${ }^{92}$ the

\footnotetext{
${ }^{88}$ This is the case in respect of anti-dumping and subsidies and countervailing measures under the WTO. See in this regard Article VI:1 of GATT 1994, Article 3.7 of the Antidumping Agreement, and Article 15.7 of the Agreement on Subsidies and Countervailing Measures.

${ }^{89}$ As under NAFTA, ASEAN, CETA, SADC, MERCOSUR, EFTA Court etc

${ }^{90}$ See Indo-Nepal Treaty of Trade concluded in 2009. Available at http://commerce.nic.in/trade/nepal.pdf (last visited, June 2018). Article XI on DSM states "In order to facilitate effective and harmonious implementation of this Treaty, the Contracting Parties shall consult each other regularly". Dispute settlement under GATT 1947 is an example of such a diplomatic process. See David Palmeter and Petros C Mavroidis, Dispute Settlement in the World Trade Organization: Practice and Procedure (Springer, 1999); Robert E Hudec, Enforcing International Trade Law: The Evolution of the Modern GATT Legal System (Butterworth, 1993); and Michael J. Trebilcock \& Robert Howse, The Regulation of International Trade, 3rd ed. (Routledge, 2005).
}

${ }^{91}$ It is important to note that EFTA Court here should not be understood as other DSMs under RTAs which adjudicate matters arising from the substantive parts of the treaty forming such RTAs. Chapter XVII of the EFTA Convention dealing with consultation and Dispute Settlement as well as relevant Annexes are the only provisions that cover disputes arising from non-compliance with a provision of the EFTA Convention by any of EFTA's member states. See Convention Establishing the European Free Trade Association, Consolidated version, (last amended on 1 July 2013). Available at http://www.efta.int/sites/default/files/documents/legaltexts/efta-convention/Vaduz\%20Convention\%20Agreement.pdf (last visited, June 2018). However, no dispute has so far been recorded on the basis of Chapter XVII of the EFTA Convention.

${ }^{92}$ It is important to note that unlike other DSMs under RTAs, EFTA Court does not have the mandate to adjudicate on matters arising out of non-compliance by any of the EFTA states with EFTA Convention. In other 
purpose of most of the RTA DSMs seem only to provide an "objective assessment of the dispute before it,... (including an examination of the facts of the case and the applicability of and conformity with the sections of the Agreement or any covered agreements) and its findings and recommendations in relation to the case". ${ }^{93}$ Moreover, the same reasons advanced in contemporary scholarships for the proliferation of RTAs are seemingly the same ones that many countries would advance for the creation of DSM under RTAs. ${ }^{94}$ It is easier and cheaper to engage with a DSM at a regional level than under the WTO. And for developing countries who may find it too expensive and onerous to bring cases under the WTO DSM, regional DSM seems cheaper and easier to navigate. There is also a strong case to be made that RTAs that contain DSMs, may facilitate a rapid and deeper integration process of the region concerned although some contracting parties to some of the RTAs with enhanced DSM do not seem to believe in such DSM. ${ }^{95}$

It is nowadays uncontested that the notion of normative development of international rules is an essential function of international courts and tribunals. ${ }^{96}$ While there is contestation as to the role of international courts and tribunals as judicial law makers, there is relatively little such contestation with regards to the decisions of international courts and tribunals as 'authoritative point of reference in the development of international law' ${ }^{97}$ Nonetheless, if

words, it is not really a court to adjudicate on the compatibility of measures by EFTA member states with EFTA Agreement. Its key objective beyond ruling on matters arising out of a member states non-compliance with the EEA Agreement, is to "to hear actions for nullity by EFTA States as well as by individuals and economic operators against decisions of the EFTA Surveillance Authority, and to rule on the interpretation of EEA law upon the request of a national court of an EFTA State. Individuals and economic operators have therefore broad access to the Court". See Carl Baudenbacher, EFTA Court, Legal Framework and Case Law, $3^{\text {rd }}$ Ed.,

(Luxembourg, 2008).

${ }^{93}$ See For instance, ASEAN Protocol on Enhanced Dispute Settlement Mechanism Article 7.

${ }^{94}$ A lot has been written on the rationale behind the formation of RTAs. For instance, see Colin B. Picker, Regional Trade Agreements V. The WTO: A Proposal for Reform of Article XXIV to Counter this Institutional Threat, 26:2 University of Pennsylvania Journal of International Economic Law (UPJIEL) (2005), pp. 267-319; Ngangjoh-Hodu, Regionalism in the WTO and the legal status of a development agenda in the EU/ACP economic partnership agreement, 78:2 Nordic Journal of International Law (2009), pp. 225-248; Gene M. Grossman, The Purpose of Trade Agreements, NBER Working Papers 22070, (2016). And for a discussion of this from the perspective of the ASEAN, see Lin Chun Hung, ASEAN Charter: Deeper Regional Integration Under International Law?, 9: 4 CJIL (2010), pp. 821-837.

\footnotetext{
95 Ibid, Lin Chung Hung on ASEAN .

${ }^{96}$ See Christian Tams \& James Sloan ed. The Development of International Law by the International Court of Justice, (OUP, 2013), p. 3

${ }^{97}$ Ibid at p. 3.
} 
the phrase 'contribution' to the development of international law means actual disputes that have broken new ground and produced principles or substantive ideas that other international tribunals, academics and practising lawyers can readily refer to,${ }^{98}$ then it is fair to conclude that these new 'regional courts' have very little, if anything, to offer. For the reasons explained in section IV above, very few disputes have gone through many of these regional DSMs. ${ }^{99}$ As pointed out above, even in situations where the subject matter of a particular case falls within the remit of one of these tribunals, countries still prefer their cases to be handled within the WTO DSM. ${ }^{100}$

However, if the word 'contribution' is used with reference to particular novelty to the substantive rules and procedures for the settlement of disputes under regional DSMs, there are indeed, identifiable features of RTA DSMs that are certainly a novelty. Some of the RTAs have addressed certain perennial problems academics and WTO negotiators have been unable to find a permanent solution to since the WTO DSM was instituted over 20 years ago. Over the years, WTO Members have been unable to come up with a definitive answer to the question of whether Article 21.5 of the DSU, which covers procedures on the level of compliance, or Article 22.2, which covers procedures on the level of retaliation, should be invoked first. ${ }^{101}$ Although in some instances, this so-called 'sequencing' problem has been partially resolved through the use of an individual 'sequencing agreement', a permanent solution has so far eluded the WTO membership. ${ }^{102}$ Conversely, to avoid the sequencing problem where a complainant could unilaterally retaliate while a compliance review

\footnotetext{
${ }^{98}$ For instance, the Permanent Court of International Law and subsequently, the International Court of Justice has been lauded for making 'a tangible contribution to the development and clarification of the rules and principles of international law'. See Christian Tams \& James Sloan ed. The Development of International Law by the International Court of Justice, (OUP, 2013), p. 3, citing H Lauterpacht, The Development of International Law by the International Court, (London, Stevens \& Sons, 1958).

${ }^{99}$ As explained above, the high reputation earned by the WTO DSM over the years together with the fact that most of the DSMs provided under RTAs remain very much untested partly explain why parties still prefer to bring their cases before the WTO DSM than before the resolution mechanisms provided under RTAs.

${ }^{100}$ See AB Report on Thailand - Cigarettes where ASEAN could have been an appropriate jurisdiction to hear the case although the Philippines and Thailand still opted for the WTO DSM to settle the case.

${ }^{101}$ On the problem of sequencing in the WTO DSU, see Jason E. Kearns and Steve Charnovitz, 'Adjudicating Compliance in the WTO: A Review of DSU Article 21.5', 5: 2 Journal of International Economic Law (2002), pp. 331-352; Ngangjoh-Hodu, 'Third Party Rights and the Concept of Legal Interest in World Trade Organization Dispute Settlement: Extending Participatory Rights to Enforcement Rights', 38:5 Journal of World Trade (2004), pp. 757-772; Victor Mosoti, 'Africa in the First Decade of WTO Dispute Settlement', 9:2 Journal of International Economic Law (2006), pp. 427-453; Yuka Fukunaga, 'Securing Compliance Through the WTO Dispute Settlement System: Implementation of DSB Recommendations', 9:2 Journal of International Economic Law, Vol. 9, Issue 2 (2006), pp. 383-426.

${ }^{102}$ See Clove - Cigarettes, where the issue of sequencing resurfaced, AB Report, United States - Measures Affecting the Production and Sale of Clove Cigarettes, WT/DS406/AB/R (adopted 24 April 2012).
} 
procedure is still on-going, some of the RTAs' adjudicatory bodies have specifically made retaliation contingent upon a panel finding that the respondent has not complied with the original report. ${ }^{103}$

Implementing the rulings and recommendations of the Dispute Settlement Body (DSB) within a reasonable period of time has always been a challenging topic both within the WTO and within academic circles. The emphasis on the surveillance and implementation of decisions clearly indicates that the present procedures of the DSU fail to provide WTO Members with effective protection in cases where DSB recommendations are not implemented or where implementation is delayed. Although the idea of issuing provisional measures to prevent irreparable damage being caused by continuous violation has long been suggested by some WTO Members in the context of the DSU reform process, ${ }^{104}$ the WTO has failed to reach a consensus on this issue. Contrary to the position under the WTO DSU, many recent DSMs under RTAs that follow quasi-judicial and judicial methods allow for the application of provisional measures pending the hearing of cases on their merits. ${ }^{105}$

Furthermore, while temporary financial compensation pending compliance with DSB rulings and recommendations is generally alien to or seen as incongruous with the WTO DSM, ${ }^{106}$ some DSMs under RTAs have embraced financial compensation as an appropriate remedy for non-compliance with rules. ${ }^{107}$ One of the reasons advanced in support of avoiding

${ }^{103}$ See, for instance, Article 10(1) of Chapter 16 of the Singapore - Australia FTA; Article 19.17(4) of the FTA between the Separate Customs Territory of Taiwan, Penghu, Kinmen and Matsu; Article 21.16(2) of the Panama, Colombia United States FTA; Article 123 of the Japan - Vietnam FTA; and Article 20.14(2) of the Korea Singapore FTA.

104 Roberto Rios-Herran \& Mateo Diego Fernandez, 'The Reform of the WTO Dispute Settlement Understanding: A Closer Look at the Mexican Proposal', 1:1 Manchester Journal of International Economic Law (2004), pp. 4-23; Jayant Raghu Ram, 'Revisiting the Idea of Provisional Measures in the WTO Dispute Settlement Mechanism’, 26 Florida Journal of International Law (2014), pp. 197-222.

105 See for instance, Article 35 of the COMESA Treaty, which confers on the court established under the treaty the power to make interim orders. See also Article XIX of the Agreement Establishing the Caribbean Court of Justice and Article 28 of the Protocol on Southern African Development Community (SADC) Tribunal.

${ }^{106}$ However, there have so far been two separate disputes involving the transfer of money by one WTO Member to another. These are (1) US - Section 110(5) of US Copyright Act, WT/DS160 (26 January 2003), where EUR $1,219,900$ per year was to be paid); and (2) the MOU between the US and Brazil in US - Cotton Subsidies, WT/DS267 (21 March 2005). The latter is available at https://ustr.gov/sites/default/files/20141001201606893.pdf

${ }^{107}$ Examples of RTAs' DSMs that provide for compensation as temporary remedies include the following: EFTA-Albania, EFTA-Mexico, EU-Cameroon EPA, ASEAN-India, ASEAN-Japan, ASEAN (AFTA), Australia-Chile, Canada-Chile, Canada-Colombia, Canada-Costa Rica, Chile-China, Chile-Colombia, ChinaCosta Rica, EFTA-Chile, EFTA-Peru, EU-CARIFORUM States EPA, EU-Chile, EU-Eastern and Southern African States interim EPA, EU-Korea, India-Singapore, India-Japan, India-Malaysia, Japan-Mexico, Japan- 
financial compensation in the WTO DSM is the difficulties inherent in administering such a system multilaterally. In this regard, where relatively few parties are involved, introducing financial compensation in the context of RTA DSMs would relatively be easier and may go a long way to enhance the system of remedies provided under such RTAs.

\section{Conclusion}

On the basis of the foregoing assessment, it is submitted that the contributions made by regional trade 'courts' to the development of international law in general and international economic law in particular remain relatively minimal. As discussed above, while the agreements establishing many of these international trade judicial bodies have in some instances sought to address some of the shortcomings of the WTO DSU, ${ }^{108}$ the principles of interpretation developed in the few cases that have gone through the regional mechanisms are largely drawn from the WTO DSM. ${ }^{109}$ Indeed, many of these agreements specifically require their DSMs to follow the jurisprudence of WTO DSB. ${ }^{110}$ Consequently, while the emergence of these fragmented DSMs may in some ways be celebrated for setting new institutional norms and arguably clarifying lacunae in international trade law, the WTO DSMs will continue, at least in the short term, to play a role in integrating different sub-fields of international trade law into the broader context of international law. Therefore, the existence of these 'regional trade courts', paradoxically, does not perturb the existence of WTO DSM. Although the situation may alter in the longer term because of the emergence of mega RTAs like the Comprehensive and Progressive Agreement for Trans-Pacific Partnership (CPATPP) $)^{111}$ and the Trans-Atlantic Trade and Investment Partnership Agreement, ${ }^{112}$ which will usher in new regional tribunals, one important lesson drawn from the analyses in this paper is that even with the increase in the number of DSM under RTAs, the WTO DSM remains the main international tribunal for the settlement of world trade disputes. Moreover,

Peru, Korea-Singapore, Korea-Chile, US-Australia, US-Colombia, and US-Panama, Japan-Thailand, USBahrain, China-New Zealand.

${ }^{108}$ In addition to those mentioned above, some of the RTA DSMs are also more transparent than the WTO Dispute Settlement System.

${ }^{109}$ See Article 14.16 of the Korea-EU FTA.

${ }^{110}$ See Article 29 of the Ukraine - Moldova FTA and footnote 1 of Article 2115.1(b) Canada - Colombia FTA.

${ }^{111}$ With the withdrawal of the US from the TPP in January 2017, in March 2018, the 11 remaining countries negotiated and signed the CPATPP which incorporates most of the provision of the TPP.

112 The Trans-Atlantic Trade and Investment Partnership Agreement had not been concluded at the time of writing this paper. 
the article has also shown that it is very difficult to conclude that the proliferation of DSMs under the RTAs threatens in any way the existence of the WTO DSM. Therefore, that the existence of multiple RTAs DSMs can also be seen as guarantees that international commitment under such RTAs will be enforced by contracting parties rather than as third parties adjudicatory bodies with relevant jurisprudential precedents. 